\title{
Study of CO Oxidation on Well-Characterized Pt-Ru/C Electrocatalysts Having Different Composition
}

\author{
Myoungki Min, Joohoon Kim, ${ }^{*}{ }^{\dagger}$ and Hasuck Kim* \\ Department of Chemistry, Seoul National University, Seoul 151-742, Korea.*E-mail: hasuckim@snu.ac.kr \\ ${ }^{\dagger}$ Department of Chemistry and Research Institute for Basic Sciences, Kyung Hee University, Seoul 130-701, Korea \\ *E-mail:jkim94@khu.ac.kr \\ Received October 15, 2009, Accepted December 1, 2009
}

\begin{abstract}
In this paper, we characterized bimetallic $\mathrm{Pt}-\mathrm{Ru} / \mathrm{C}$ alloy catalysts having four different compositions and compared the catalytic activities of the prepared alloys for CO oxidation. ICP-AES, EDS, XRD, TEM, and XAS were used to investigate the composition, degree of alloying, particle size, and electronic structure of the prepared $\mathrm{Pt}-\mathrm{Ru} / \mathrm{C}$ catalysts. Those results indicated the synthesis of the alloy catalysts with intended composition and uniform size. The electrochemical study of the characterized alloys showed higher catalytic activity for CO oxidation than that of the commercial Pt/C (E-TEK, Inc., $20 \mathrm{wt} \%$ ) catalyst. Especially, it was shown that the alloy catalyst with Ru composition of 50 atomic $\%$ gave the highest catalytic activity for $\mathrm{CO}$ oxidation.
\end{abstract}

Key Words: Pt-Ru/C catalyst, $\mathrm{CO}$ oxidation

\section{Introduction}

In this study, we reported well-characterized $\mathrm{Pt}-\mathrm{Ru} / \mathrm{C}$ alloy catalysts and compared their electrocatalytic activities for $\mathrm{CO}$ oxidation depending on catalyst composition. The atomic ratios of Pt to Ru were 3, 2, 1, and 0.33. ICP-AES (inductively coupled plasma-atomic emission spectroscopy), EDS (energy dispersive X-ray spectroscopy), XRD (X-ray diffraction), TEM (transmission electron microscopy), and XAS (X-ray adsorption spectroscopy) were used to characterize the composition, degree of alloying, particle size, and electronic structure of the $\mathrm{Pt}-\mathrm{Ru} / \mathrm{C}$ electrocatalysts. CO (carbon monoxide) ASV (anodic stripping voltammetry) of the $\mathrm{Pt}-\mathrm{Ru} / \mathrm{C}$ catalysts indicated that the apparent electrocatalytic activity of the $\mathrm{Pt}-\mathrm{Ru} / \mathrm{C}$ catalysts was far superior to that of $\mathrm{Pt} / \mathrm{C}$, and that the best activity for $\mathrm{CO}$ oxidation was achieved by the catalyst with the ratio of $\mathrm{Pt} / \mathrm{Ru}=1$.

There have been significant efforts to develop efficient catalysts for $\mathrm{CO}$ oxidation. ${ }^{1-7}$ Good catalysts for $\mathrm{CO}$ oxidation are required when hydrocarbons are reformed to produce $\mathrm{H}_{2}$ fuel gas for use in PEMFC (polymer electrolyte membrane fuel cell). ${ }^{8}$ Conventional Pt anodic catalysts in PEMFC are severely deactivated by $\mathrm{CO}$ gas, which is produced as well during the steamreforming of hydrocarbons (e.g. $10 \sim 1000 \mathrm{ppm}),{ }^{9}$ even in trace amount $(10 \mathrm{ppm}){ }^{10,11}$ Several different catalysts have been proposed for the catalytic oxidation of CO; for example, Pt-Ru, $\mathrm{Pt}-\mathrm{Sn}, \mathrm{Au}-\mathrm{Ag}$ etc. ${ }^{12-20}$ Especially, Pt-Ru alloy has obtained special interest as a catalyst for $\mathrm{CO}$ oxidation based on theoretical and empirical studies of CO oxidation mechanisms. ${ }^{21-27}$

Two mechanisms have been proposed to explain the activities of Pt-based catalysts. One is the bifunctional mechanism proposed by Watanabe and his colleagues. ${ }^{28-31}$ It is based on the promotion of $\mathrm{CO}$ oxidation on $\mathrm{Pt}$ atoms by a second metal which provides $\mathrm{OH}$-type species at lower potential. The more oxidizable second metal, thus, promotes $\mathrm{CO}$ electrooxidation. The other one is the ligand mechanism, which is based on modification of electronic property of the Pt by a second metal in the catalyst. $^{32-35}$ The modified electronic property results in the different chemisorption property (or lower desorption energy) of the catalyst for $\mathrm{CO}$ so that the $\mathrm{CO}$ coverage on the Pt sites used for $\mathrm{H}_{2}$ oxidation is reduced. However, the mechanisms responsible for enhanced activity for $\mathrm{CO}$ oxidation still remain controversial.

The study described here is an extension of our previous works in which we fabricated high metal content Pt-Ru alloy catalysts on various carbon blacks and electrodeposited Pt-Ru catalysts on Nafion ${ }^{\circledR}$-bonded carbon layer. Previously, we investigated high metal content catalysts on various carbon supports and showed the catalysts exhibited homogeneous dispersion as the specific areas of supporting materials increase. ${ }^{23} \mathrm{We}$ also evaluated performance of Pt-Ru catalysts prepared on Nafion ${ }^{\circledR}$ bonded carbon layer by electrodeposition. ${ }^{22}$ However, we have not explored the effect of composition of the Pt-Ru alloy catalysts on $\mathrm{CO}$ oxidation. Much interest has been devoted to investigate the dependence of $\mathrm{CO}$ oxidation on the composition of Pt-Ru alloy catalysts recently. ${ }^{12,24,27,36}$ Therefore, the present study aims to investigate the effect of the important factor, i.e. composition of the Pt-Ru alloy catalysts, on the electrochemical and electronic properties of the catalysts for the catalytic oxidation of $\mathrm{CO}$.

In this paper, we reported the synthesis of bimetallic $\mathrm{Pt}-\mathrm{Ru} / \mathrm{C}$ electrocatalysts having four different atomic ratios of $\mathrm{Pt}: \mathrm{Ru}$. ICP-AES, EDS, and TEM indicated that the catalysts were uniform in composition and size. XRD and XANES spectrometry also showed that the $\mathrm{Pt}-\mathrm{Ru} / \mathrm{C}$ catalysts existed in a type of solid solution rather than a physical mixture of two metals. Following complete characterization, the catalysts were deposited with Nafion ${ }^{(B}$ on the surface of a glassy carbon electrode and their electrochemical activities were measured as a function of composition using $\mathrm{CO}$ anodic stripping voltammetry (ASV). The results indicated that the prepared $\mathrm{Pt}-\mathrm{Ru} / \mathrm{C}$ catalysts showed better catalytic activity for $\mathrm{CO}$ oxidation than the commercial $\mathrm{Pt} / \mathrm{C}$ catalyst (E-TEK, Inc., $20 \mathrm{wt} \%$ ). The highest activity for 
$\mathrm{CO}$ oxidation was obtained with the $\mathrm{Pt}-\mathrm{Ru} / \mathrm{C}$ catalyst containing $50 \% \mathrm{Ru}$.

\section{Experimental Section}

Preparation of $\mathbf{P t}-\mathbf{R u} / \mathbf{C}$ electrocatalysts. $\mathrm{Pt}-\mathrm{Ru} / \mathrm{C}$ catalysts were prepared as previously described with some modifications. ${ }^{30}$ Briefly, chloroplatinic acid $(0.01 \mathrm{M})$ was reduced by adding powdered sodium bisulphate ( $c a .4 \mathrm{~g}$ ) which accompanied by evolution of hydrogen chloride and resulted in the production of a colorless soluble intermediate of platinum. The color of the solution changed slowly to clear yellow when hydrogen peroxide ( $35 \mathrm{wt} \%, c a .50 \mathrm{~mL}$ at $1 \mathrm{~mL} / \mathrm{min}$ ) was added. During the formation of the yellow metastable form of the oxidized platinum species, the $\mathrm{pH}$ was carefully controlled at $c a$. 5 by adding sodium hydroxide solution (5 wt \%). Appropriate amount of ruthenium chloride solution was then added dropwise to the yellow solution, which leaded to the formation of a brown colloidal product accompanying a vigorous evolution of oxygen. The $\mathrm{pH}$ of the solution was again adjusted to $c a$. 5 throughout this process. Carbon black substrate (Vulcan XC-72R, $24 \mathrm{~m}^{2} / \mathrm{g}$ BET, Cabbot Co.) was added to the vigorously stirred colloidal solution in the presence of hydrogen bubbling after the oxygen evolution subsided. After the deposition of clusters was completed, the supported catalysts were filtered and washed thoroughly to remove traces of chlorides. The catalysts were dried overnight at room temperature. The loading of metals on the carbon substrate was estimated by ICP-AES measurement of retrieved filtrate solution.

Characterization of Pt-Ru/C electrocatalysts. The composition of the catalysts was studied by ICP-AES and EDS. The amounts of metals lost during the preparation of catalysts were calculated by comparing the atomic emission from the retrieved metal precursor solution during synthesis to standards. An ICPAES (Flasmascan 8410, Labtam Co.) was used to obtain the calibration curve and to measure atomic emission intensity of the retrieved filtrate solution. An EDS (QX-2000, Link Co.) attached to a scanning electron microscope (SEM, JSM-840A, Jeol Co.) was also used to analyze the atomic composition of the prepared catalysts. The composition was calculated by integrating the area of $\mathrm{Pt} \mathrm{M}_{\alpha}$ and $\mathrm{Ru} \mathrm{K}_{\alpha}$ lines accumulated for $150 \mathrm{~s}$ from several randomly selected sections.

The size and structure of the catalysts were probed by TEM and XRD. A TEM (JEM-200CX, Jeol Co.) was used to characterize both morphology and size of the prepared catalysts. XRD experiments were carried out using a diffractometer (CN2115, Rigaku Co.) with nickel-filtered $\mathrm{Cu} \mathrm{K}_{\alpha}$ radiation at a scan rate of $3 \% \mathrm{~min}$ (2-theta). The X-ray source was operated at $40 \mathrm{kV}$ and $30 \mathrm{~mA}$. The prepared catalyst powders were mounted on glass slides.

Electrochemical measurement of Pt-Ru/C electrocatalysts. The electrochemical behavior of the catalysts was probed using Nafion ${ }^{\circledR}$-impregnated electrodes prepared as follows. A mixture of catalysts, Nafion ${ }^{\circledR}$ solution, triethylphosphate (TEP), and water was ultrasonicated for $10 \mathrm{~min}$. TEP (3-fold mass excess of the dry Nafion ${ }^{\circledR}$ ) was used to heat above the glass transition temperature $\left(140^{\circ} \mathrm{C}\right)$ of Nafion $^{\circledR}$, which is necessary to obtain a well recast ionomer as noted in previous reports. ${ }^{37,38}$ A measured vol- ume of the mixture was dropped on a glassy carbon electrode and dried at room temperature. The electrode was then heated at $160{ }^{\circ} \mathrm{C}$ for $30 \mathrm{~min}$ to remove TEP. ${ }^{37}$ The resulting electrode was rinsed with water and equilibrated in $1.0 \mathrm{M} \mathrm{H}_{2} \mathrm{SO}_{4}$ solution. All electrochemical experiments were carried out in a single-component glass cell using standard three-electrode configuration with a Pt-gauze counter electrode and a saturated calomel reference electrode (BAS Inc.). The experiments were performed using a computer-controlled electrochemical analyzer (BAS $100 \mathrm{~B} / \mathrm{W}$, BAS Inc.) at room temperature. Cyclic voltammetry (CV) was used to determine the electrochemical surface area and particle size. The surface area was calculated by integrating the area under the hydrogen-adsorption peaks in cyclic voltammograms. Since the catalysts loading of the Nafion ${ }^{\circledR}$ film was known, it was possible to determine the specific catalyst area $\mathrm{S}\left(\mathrm{m}^{2} / \mathrm{g}\right)$ and the average particle size $\mathrm{d}(\mathrm{nm})$ assuming spherical particles; $d=6.0 \times 10^{3} /(21.4 \times \mathrm{S})$ where 21.4 is the density of platinum $\left(\mathrm{g} / \mathrm{cm}^{3}\right) .{ }^{39} \mathrm{CO}$ anodic stripping voltammetry was performed to estimate the electrocatalytic activities of the catalysts. $\mathrm{CO}$ was adsorbed at $0.15 \mathrm{~V}$ in $\mathrm{CO}$ saturated $1.0 \mathrm{M} \mathrm{H}_{2} \mathrm{SO}_{4}$ solution for $3 \mathrm{~min}$, and a potential scan $(v=0.01 \mathrm{~V} / \mathrm{s})$ was then applied after $\mathrm{CO}$ had been purged completely from the solution.

XANES measurement of Pt-Ru/C electrocatalysts. The electronic structure of the catalysts was studied by X-ray adsorption near edge structure (XANES) spectroscopy. XANES experiments were carried out in the transmission mode at the Pohang Accelerator Laboratory (PAL) using the beamline 3C1. The monochromator was a $\mathrm{Si}$ (111) double flat crystal with an energy resolution $(\Delta \lambda / \lambda)$ of $2.0 \times 10^{-4}$ at $10 \mathrm{keV}$. Two inline gas ionization detectors were used to measure the intensity of incident and transmitted beams. The data analysis for XAS (X-ray adsorption spectroscopy) was performed by the standard procedure as described previously. ${ }^{40,41}$ The inherent background was removed by fitting a polynomial to the pre-edge region. The preedge fit was extrapolated beyond the edge and subtracted from the total absorption. The resulting spectra, $\mu(E)$, were normalized to an edge jump of unity for comparing the XANES features directly with one another.

\section{Results and Discussion}

Composition characterization of $\mathrm{Pt}-\mathrm{Ru} / \mathrm{C}$ electrocatalysts. To determine the chemical composition of the prepared Pt-Ru/C catalysts, ICP-AES and EDS measurements were performed. The EDS measurements of the catalysts show atomic compositions of the prepared catalysts are close to intended compositions (Table 1). We also measured the amounts of metals lost during the preparation of the $\mathrm{Pt}-\mathrm{Ru} / \mathrm{C}$ catalysts using ICP-AES. For ICP-AES measurement, the unbound precursor metals were retrieved during synthesis. Their concentrations were then determined by comparing the atomic emission from the retrieved metal precursor solution during synthesis to standards as described in the Experimental Section. Table 1 shows the amounts of metals lost during the preparation of catalysts are small, which indicates the synthesis of $\mathrm{Pt}-\mathrm{Ru} / \mathrm{C}$ catalysts with intended composition.

XRD and TEM measurement of Pt-Ru/C electrocatalysts. $\mathrm{XRD}$ spectra of the $\mathrm{Pt}-\mathrm{Ru} / \mathrm{C}$ catalysts were obtained to inves- 
Table 1. EDS, ICP-AES, XRD, XANES, and electrochemical measurements of Pt-Ru/C catalysts.

\begin{tabular}{cccccc}
\hline Catalyst & Composition/Pt $: \mathrm{Ru}$ & Loss $^{b} / \mathrm{Pt}, \mathrm{Ru}$ & Lattice parameter $^{c} / \AA$ & d-band vacancy $^{d}$ & Particle size $^{e} / \AA$ \\
\hline $\mathrm{Pt}_{3} \mathrm{Ru} / \mathrm{C}$ & $75: 25(71.1: 28.9)^{a}$ & $0.8 \%, 0.2 \%$ & 3.904 & 0.307 & $24.4(21.2)^{f}$ \\
$\mathrm{Pt}_{2} \mathrm{Ru} / \mathrm{C}$ & $66: 33(66.2: 34.8)^{a}$ & $7.5 \%, 2.6 \%$ & 3.896 & 0.309 & $24.3(22.4)^{f}$ \\
$\mathrm{PtRu} / \mathrm{C}$ & $50: 50(43.7: 56.3)^{a}$ & $0.1 \%, 0.8 \%$ & 3.868 & 0.312 & $24.1(24.8)^{f}$ \\
$\mathrm{PtRu}_{3} / \mathrm{C}$ & $25: 75(27.9: 72.1)^{a}$ & $0.5 \%, 0.2 \%$ & 3.847 & 0.318 & $23.9(25.9)^{f}$ \\
\hline
\end{tabular}

${ }^{a}$ The composition from EDS measurement; ${ }^{b}$ The loss from ICP-AES measurement; ${ }^{c}$ The lattice parameter from XRD measurement; ${ }^{d}$ The d-band vacancy from XANES measurement; ${ }^{e}$ The particle size from XRD measurement; ${ }^{f}$ The particle size from CV measurement.

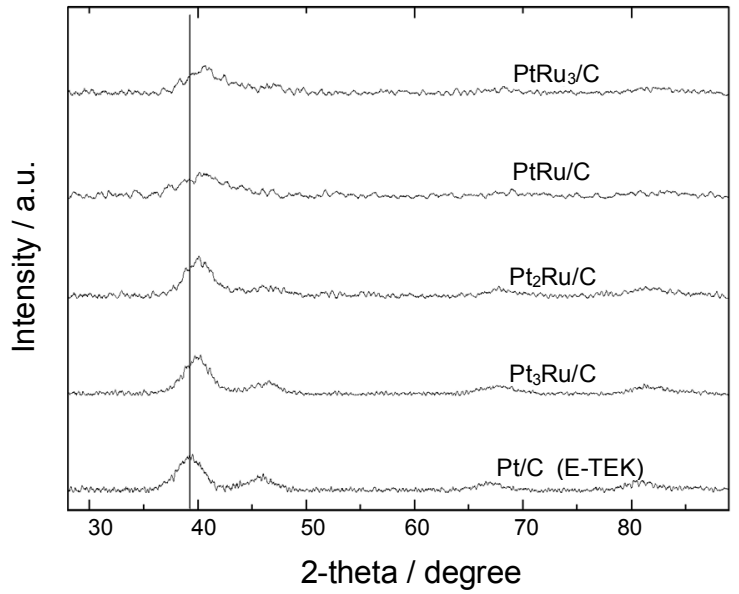

Figure 1. Powder XRD patterns of $\mathrm{Pt} / \mathrm{C}$ and $\mathrm{Pt}-\mathrm{Ru} / \mathrm{C}$ catalysts. The black line perpendicular to XRD patterns of the catalysts is shown as a visual guide.

tigate the degree of alloying and particle size of the catalysts. Figure 1 shows the XRD spectra of the prepared catalysts. A XRD spectrum of a commercial Pt/C (E-TEK Inc.) catalyst is also shown in Figure 1 for comparison. It is known that platinum and ruthenium have a face-centered cubic structure (JCPDS 4802 ) and a hexagonal close-packed structure (JCPDS 6-663), respectively. However, the formation of a ruthenium solution in platinum gives a face-centered cubic structure. ${ }^{42}$ Figure 1 shows diffraction peaks only from the face-centered cubic lattice structure, which indicates the formation of a binary alloy. Figure 1 also shows that the diffraction peaks for the $\mathrm{Pt}-\mathrm{Ru} / \mathrm{C}$ catalysts shift to the higher 2-theta values compared with ones of pure platinum $(\mathrm{Pt} / \mathrm{C}, \mathrm{E}-\mathrm{TEK})$. The penetration of the $\mathrm{Ru}$ atoms, which have a smaller atomic radius than the Pt atoms, into Pt lattices causes the contraction of lattice resulting in the shifts of diffraction peaks. The lattice parameters of $\mathrm{Pt}-\mathrm{Ru} / \mathrm{C}$ and $\mathrm{Pt} / \mathrm{C}$ are shown in Table 1. The lattice parameter decreases as the Ru concentration increases, which indicates the prepared $\mathrm{Pt}-\mathrm{Ru} / \mathrm{C}$ catalysts exist in a type of solid solution rather than a physical mixture of particles of the two metals. The average particle sizes of the prepared catalysts were calculated from the broadening of the (111) reflection of the Pt face-centered cubic lattice by using the Debye-Sherrer equation. ${ }^{43}$ Table 1 shows the calculated average particle sizes of the catalysts, which are in good agreement with ones obtained from the $\mathrm{CV}$ measurements.

The dispersion of metal particles on the carbon black was investigated by TEM measurement for both Pt/C (E-TEK, 20 wt $\%$ ) and Pt-Ru/C catalysts (Figure 2). Pt-Ru/C catalysts (Figure $2 \mathrm{~b}-2 \mathrm{e}$ ) show slightly less homogeneous dispersion of metal
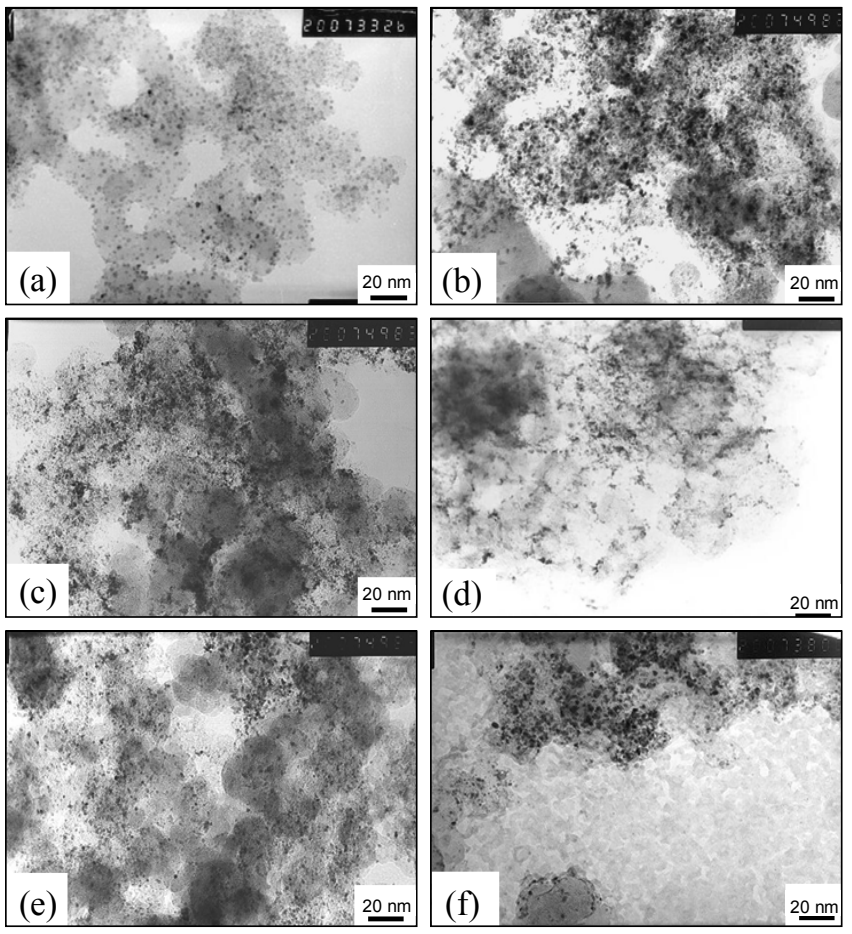

Figure 2. TEM images of (a) $\mathrm{Pt} / \mathrm{C}$ (E-TEK, Inc.), (b) $\mathrm{Pt}_{3} \mathrm{Ru} / \mathrm{C}$, (c) $\mathrm{Pt}_{2} \mathrm{Ru} /$ $\mathrm{C}$, (d) $\mathrm{PtRu} / \mathrm{C}$, (e) $\mathrm{PtRu}_{3} / \mathrm{C}$, (f) $\mathrm{Pt} / \mathrm{C}$ (E-TEK, Inc.) in Nafion ${ }^{\circledR}$ film.

particles on carbon supports than Pt/C (Figure 2a). Small agglomerates of metal particles are sporadically observed (Figure $2 \mathrm{~b}-2 \mathrm{e}$ ). The particle size of the catalysts ranges between $2 \mathrm{~nm}$ and $3 \mathrm{~nm}$, which is in good agreement with XRD and CV measurements (Table 1).

XANES measurements. XANES (X-ray absorption near edge structure) analysis was performed to measure d-band vacancy of Pt in the prepared catalysts. Pt $\mathrm{L}_{\mathrm{III}}$ and $\mathrm{L}_{\mathrm{II}}$ edge XANES spectra for Pt-Ru/C catalysts are shown in Figure 3. The values of the Pt d-band vacancies, calculated from the area under the Pt $\mathrm{L}_{\text {III }}$ and $\mathrm{L}_{\text {II }}$ edges, are listed in Table 1. It is clear that the values of the Pt d-band vacancies increase with increasing ruthenium content (Table 1), which is a consequence of the higher electron affinity of ruthenium than that of platinum. ${ }^{44}$ This result does give further support to the idea that the supported bimetallic catalysts are indeed a solid solution of $\mathrm{Pt}$ and $\mathrm{Ru}$.

Electrochemical measurements. In order to characterize the electrochemical properties of the electrocatalysts, a compact thin layer of catalytic powders and recast $\mathrm{Nafion}^{\circledR}$ was deposited on a glassy carbon electrode. Figure $2 \mathrm{f}$ shows the TEM image of a thin Nafion ${ }^{\mathbb{B}}-\mathrm{Pt} / \mathrm{C}$ (E-TEK) film, which clearly distinguishes two components of the thin Nafion ${ }^{\mathbb{B}}-\mathrm{Pt} / \mathrm{C}$ film; recast Nafion ${ }^{\circledR}$ 
(a)

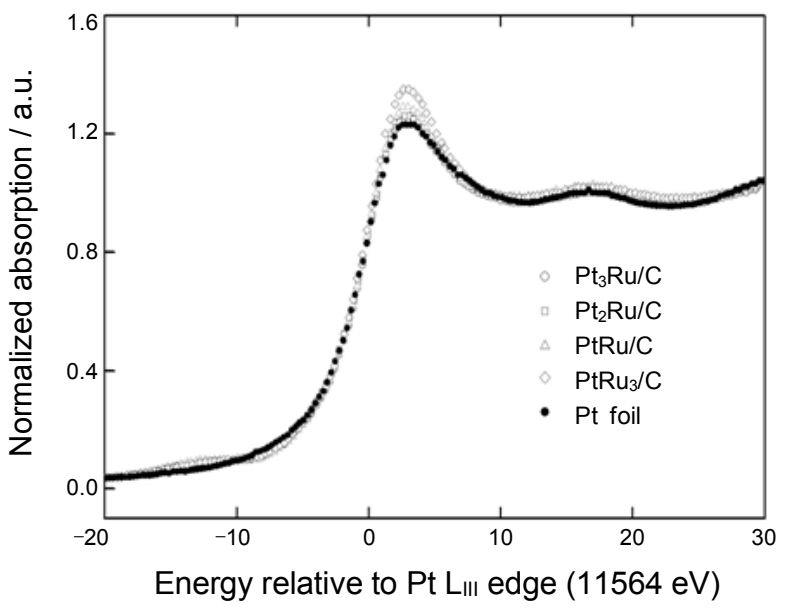

(b)

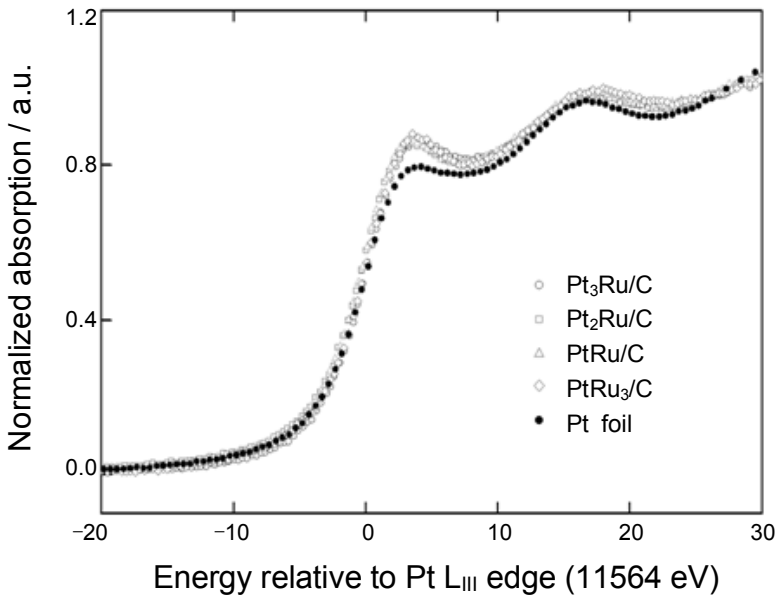

Figure 3. XANES spectra at the (a) $\mathrm{Pt} \mathrm{L}_{\text {III }}$ and (b) $\mathrm{Pt} \mathrm{L}_{\text {II }}$ edge of $\mathrm{Pt}-\mathrm{Ru} / \mathrm{C}$ catalysts.

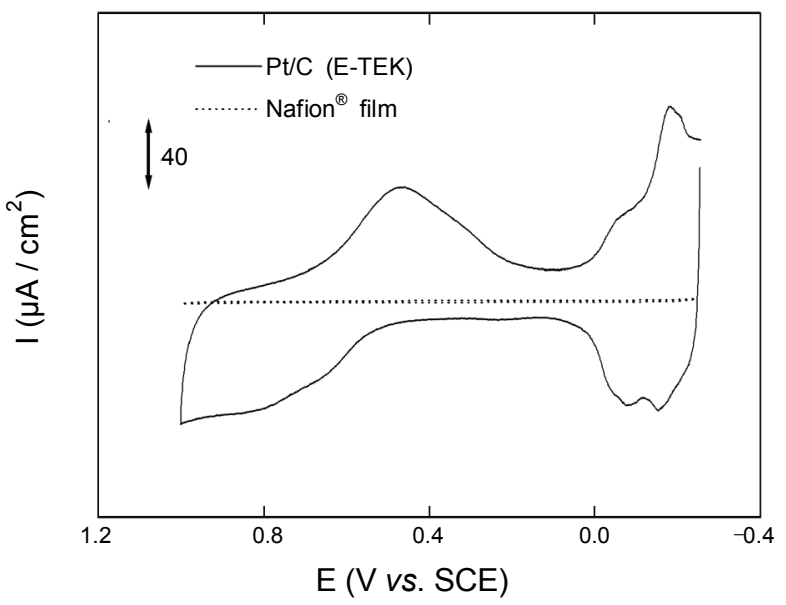

Figure 4. Cyclic voltammogram of $\mathrm{Pt} / \mathrm{C}$ (E-TEK, Inc.) catalyst in Nafion ${ }^{\circledR}$ film. The data were obtained in an aqueous $1.0 \mathrm{M} \mathrm{H}_{2} \mathrm{SO}_{4}$ electrolyte solution. The scan rate was $50 \mathrm{mV} / \mathrm{s}$.

(ionic conductor and diffusion medium) and catalytic particles (electronic conductor). The use of thin Nafion ${ }^{\circledR}$-catalyst films provided well-defined cyclic voltammograms of the catalysts. For example, the cyclic voltammogram of Pt/C (E-TEK) in the (a)

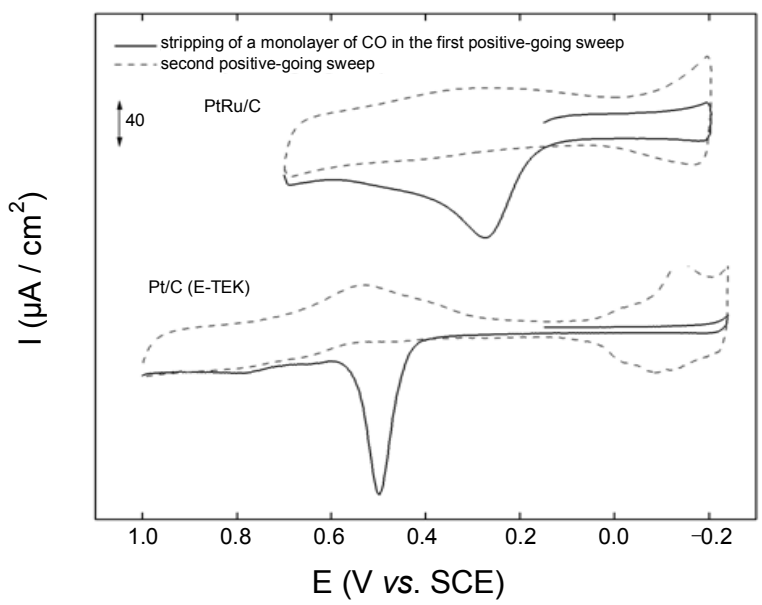

(b)

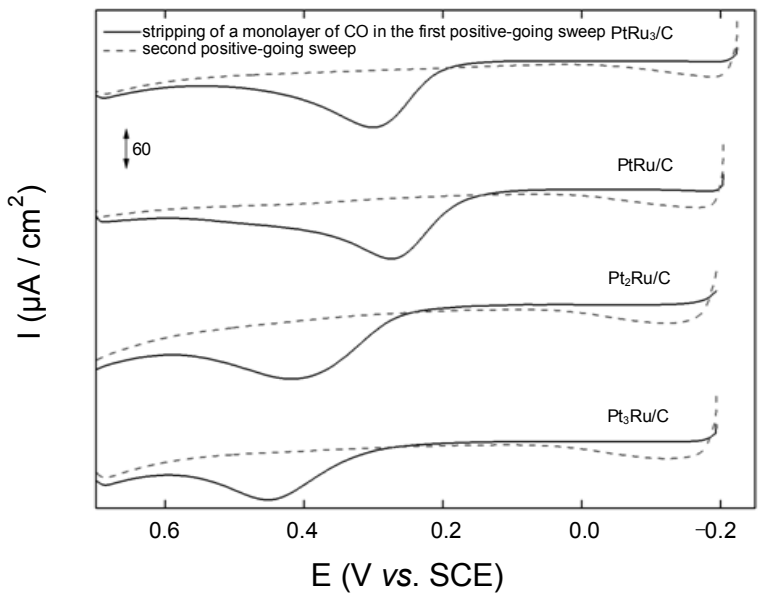

Figure 5. Co stripping voltammograms of (a) Pt/C (E-TEK, Inc.) and $\mathrm{PtRu} / \mathrm{C}$ catalyst, and (b) $\mathrm{Pt}-\mathrm{Ru} / \mathrm{C}$ catalysts. The data were obtained in an aqueous $1.0 \mathrm{M} \mathrm{H}_{2} \mathrm{SO}_{4}$ electrolyte solution. The scan rate was 50 $\mathrm{mV} / \mathrm{s}$.

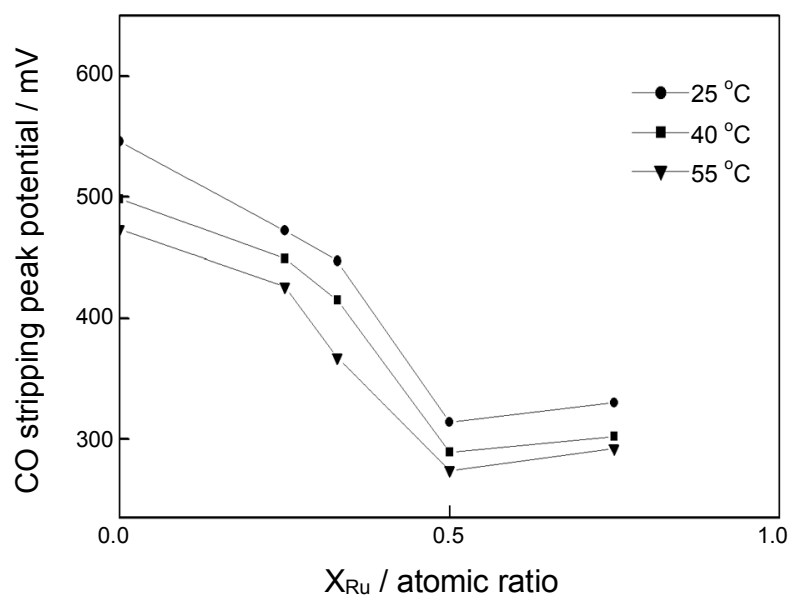

Figure 6. Relationship between the composition of $\mathrm{Pt}-\mathrm{Ru} / \mathrm{C}$ catalysts and the activity for $\mathrm{CO}$ oxidation at different temperatures.

Nafion ${ }^{\circledR}$ film shows well-defined characteristic peaks of Pt (Figure 4). Cyclic voltammograms of Pt-Ru/C catalysts were also obtained using the Nafion ${ }^{\mathrm{B}}$-catalysts films (Supporting Information, Figure S1). Assuming spherical particles, the average par- 
ticle size of catalysts was calculated from the hydrogen adsorption region in the voltammograms of the $\mathrm{Pt}-\mathrm{Ru} / \mathrm{C}$ (Table 1). ${ }^{39}$

$\mathrm{CO}$ anodic stripping analysis. CO anodic stripping voltammetry was performed to estimate the electrocatalytic activities of the catalysts. Figure 5 shows the $\mathrm{CO}$ stripping voltammograms of the $\mathrm{Pt}-\mathrm{Ru} / \mathrm{C}$ and $\mathrm{Pt} / \mathrm{C}$ catalysts. As shown in Figure 5a, the onset of the $\mathrm{CO}$ oxidation current on $\mathrm{PtRu} / \mathrm{C}$ catalyst commences at $\sim 0.1 \mathrm{~V}$, which is a significantly more negative potential than that for $\mathrm{CO}$ oxidation on Pt/C (E-TEK) catalyst. Similarly, the CO-stripping peak potential on $\mathrm{PtRu} / \mathrm{C}$ shifts $\sim 0.25 \mathrm{~V}$ negatively compared to that on $\mathrm{P} / \mathrm{C}(\mathrm{E}-\mathrm{TEK})$ catalyst. Those results indicate that the apparent electrocatalytic activity of the $\mathrm{PtRu} / \mathrm{C}$ alloy catalyst is far superior to that of $\mathrm{Pt} / \mathrm{C}$ (E-TEK). This better performance of the $\mathrm{PtRu} / \mathrm{C}$ alloy catalyst can be explained by a bifunctional mechanism for oxidation of $\mathrm{CO}^{28,29}$ Since adsorption of oxygenated species onto Ru commences at more negative potential than on $\mathrm{Pt},{ }^{45,46}$ oxygenated species are supplied to the $\mathrm{PtRu} / \mathrm{C}$ alloy catalyst at low potential, thereby facilitating the onset of the oxidation of $\mathrm{CO}$ to $\mathrm{CO}_{2}$ at a potential significantly more negative than on $\mathrm{Pt} / \mathrm{C}$. This effect leads to the higher activity for the electrooxidation of adsorbed $\mathrm{CO}$ on $\mathrm{PtRu} / \mathrm{C}$ compared to $\mathrm{Pt} / \mathrm{C}$ as shown in Figure 5a. Compared to the onset and $\mathrm{CO}$ stripping peak potential of the $\mathrm{Pt} / \mathrm{C}$ catalyst, all of the prepared $\mathrm{Pt}-\mathrm{Ru} / \mathrm{C}$ catalysts show the shifted potentials in a negative direction, which indicates that the apparent electrocatalytic activities of the $\mathrm{Pt}-\mathrm{Ru} / \mathrm{C}$ catalysts are superior to that of the commercial E-TEK Pt/C catalyst (Figure $5 b$ ). Figure 5 b also shows that the $\mathrm{PtRu} / \mathrm{C}$ catalyst with the ratio $\mathrm{Pt} / \mathrm{Ru}=1$ exhibits the most negative onset and $\mathrm{CO}$ stripping peak potential, which agrees with previous reports. ${ }^{47,27,36}$ At three different temperatures, the $\mathrm{Pt}-\mathrm{Ru} / \mathrm{C}$ alloy catalysts with the ratio $\mathrm{Pt} / \mathrm{Ru}=1$ results in the lowest $\mathrm{CO}$ oxidation peak potential as shown in Figure 6.

\section{Summary and Conclusions}

Bimetallic Pt-Ru/C alloy catalysts having different composition were characterized using ICP-AES, EDS, XRD, TEM, $\mathrm{XAS}$, and electrochemical techniques. ICP-AES and EDS measurements confirmed the synthesis of the catalysts with intended composition; atomic ratios of $\mathrm{Pt}$ to Ru were $3,2,1$, and 0.33 . The uniform size of the prepared catalysts was also verified by TEM measurement. XRD and XANES studies indicated that the prepared $\mathrm{Pt}-\mathrm{Ru} / \mathrm{C}$ catalysts formed alloy clusters rather than a physical mixture of two metals. After confirming the synthesis of alloy catalysts having intended composition and uniform size, the electrocatalytic activities of the prepared catalysts were investigated using anodic stripping voltammetry. The results showed higher catalytic activity of the prepared catalysts for $\mathrm{CO}$ oxidation than that of commercial $\mathrm{Pt} / \mathrm{C}$ catalyst (E-TEK, Inc., $20 \mathrm{wt} \%$ ). The highest activity for $\mathrm{CO}$ oxidation was obtained with the $\mathrm{Pt}-\mathrm{Ru} / \mathrm{C}$ catalyst containing 50 atomic $\% \mathrm{Ru}$, which is in good agreement with previous reports. ${ }^{27,36}$

Acknowledgments. This work was supported by a grant from the Kyung Hee University in 2009 (KHU-20090602).

Supplementary Information. Cyclic voltammograms of $\mathrm{Pt}-\mathrm{Ru} / \mathrm{C}$ catalysts are available on request from the correspond- ing author. E-mail: jkim94@khu.ac.kr; Fax: 82-2-966-3701.

\section{References}

1. Teng, Y.; Sakurai, H.; Ueda, A.; Kobayashi, T. Int. J. Hydrogen Energy 1999, 24, 355.

2. Avgouropoulos, G.; Ioannides, T.; Matralis, H. Appl. Catal. B Environ. 2005, 56, 87.

3. Scott, R. W. J.; Sivadinarayana, C.; Wilson, O. M.; Yan, Z.; Goodman, D. W.; Crooks, R. M. J. Am. Chem. Soc. 2005, 127, 1380.

4. Valden, M.; Pak, S.; Lai, X.; Goodman, D. W. Catal. Lett. 1998, $56,7$.

5. Kung, M. C.; Davis, R. J.; Kung, H. H. J. Phys. Chem. C 2007, 111, 11767.

6. Min, B. K.; Friend, C. M. Chem. Rev. 2007, 107, 2709.

7. Chang, T.; Sohn, Y. S. Bull. Korean Chem. Soc. 1986, 7, 12.

8. Ok, J.; Kim, D. W.; Lee, C.; Choi, W. C.; Cho, S.; Kang, Y. Bull. Korean Chem. Soc. 2008, $29,842$.

9. Roh, H. S.; Jun, K. W. Bull. Korean Chem. Soc. 2009, 30, 153.

10. Gottesfeld, S.; Pafford, J. J. Electrochem. Soc. 1988, 135, 2651.

11. Han, K. S.; Hwang, K. J.; Han, O. H. Bull. Korean Chem. Soc. 2007, 28, 2442.

12. Giorgi, L.; Pozio, A.; Bracchini, C.; Giorgi, R.; Turtu, S. J. Appl. Electrochem. 2001, 31, 325.

13. Ciapina, E. G.; Gonzalez, E. R. J. Electroanal. Chem. 2009, 626, 130.

14. Switzer, E. E.; Olson, T. S.; Datye, A. K.; Atanassov, P.; Hibbs, M. R.; Cornelius, C. J. Electrochim. Acta 2009, 54, 989.

15. Marques, P.; Ribeiro, N. F. P.; Schmal, M.; Aranda, D. A. G.; Souza, M. M. V. M. J. Power Sources 2006, 158, 504.

16. Arenz, M.; Stamenkovic, V.; Blizanac, B. B.; Mayrhofer, K. J.; Markovic, N. M.; Ross, P. N. J. Catal. 2005, 232, 402.

17. Chou, J.; Pai, W. W.; Kuo, C.; Lee, J. D.; Lin, C. H.; Wei, C. J. Phys. Chem. C 2009, 113, 13151.

18. Wang, C.; Yin, H.; Chan, R.; Peng, S.; Dai, S.; Sun, S. Chem. Mater. 2009, 21, 433.

19. Chang, C. M.; Cheng, C.; Wei, C. M. J. Chem. Phys. 2008, 128, 124710/1.

20. Koper, M. T. M. Surf. Sci. 2004, 548, 1.

21. Inoue, M.; Nishimura, T.; Akamaru, S.; Taguchi, A.; Umeda, M.; Abe, T. Electrochim. Acta 2009, 54, 4764.

22. Ra, Y.; Lee, J.; Kim, I.; Bong, S.; Kim, H. J. Power Sources 2009, $187,363$.

23. Han, K.; Lee, J.; Kim, H. Electrochim. Acta 2006, 52, 1697.

24. Klerke, A.; Saadi, S.; Toftegaard, M. B.; Madsen, A. T.; Nielsen, J. H.; Jense, S.; Hansen, O.; Christensen, C. H.; Quaade, U. J. Catal. Lett. 2006, 109, 7.

25. Maillard, F.; Lu, G.-Q.; Wieckowski, A.; Stimming, U. J. Phys. Chem. B 2005, 109, 16230.

26. Spendelow, J. S.; Babu, P. K.; Wieckowski, A. Curr. Opin. Solid State Mater. Sci. 2005, 9, 37.

27. Coutanceau, C.; Rakotondrainibe, A. F.; Lima, A.; Garnier, E.; Pronier, S.; Leger, J.-M.; Lamy, C. J. Appl. Electrochem. 2004, 34, 61.

28. Watanabe, M.; Motoo, S. J. Electroanal. Chem. 1975, 60, 275.

29. Watanabe, M.; Motoo, S. J. Electroanal. Chem. 1975, 60, 267.

30. Watanabe, M.; Uchida, M.; Motoo, S. J. Electroanal. Chem. 1987, 229, 395.

31. Yajima, T.; Wakabayashi, N.; Uchida, H.; Watanabe, M. Chem. Commun. 2003, 828.

32. Krausa, M.; Vielstich, W. J. Electroanal. Chem. 1994, 379, 307.

33. Frelink, T.; Visscher, W.; van Veen, J. A. R. Surf. Sci. 1995, 335, 353.

34. Tong, Y.; Kim, H. S.; Babu, P. K.; Waszczuk, P.; Wieckowski, A.; Oldfield, E. J. Am. Chem. Soc. 2002, 124, 468.

35. Davies, J. C.; Bonde, J.; Logadóttir, Á.; Nørskov, J. K.; Chorkendorff, I. Fuel Cells 2005, 4, 429.

36. Wei, Z. D.; Chan, S. H. J. Electroanal. Chem. 2004, 569, 23.

37. Gloaguen, F.; Andolfatto, F.; Durand, R.; Ozil, P. J. Appl. Electro- 
chem. 1994, 24, 863.

38. Gebel, G.; Aldebert, P.; Pineri, M. Macromolecules 1987, $20,1425$.

39. Kabbabi, A.; Gloaguen, F.; Andolfatto, F.; Durand, R. J. Electroanal. Chem. 1994, 373, 251.

40. Sayers, D. E.; Bunker, B. A. X-ray Absorption: Principles, Applications, Techniques of EXAFS, SEXAFS and XANES; Wiley-Interscience: New York, 1988.

41. Lytle, F. W. Applications of Synchrotron Radiation; Gordon and Breach Science: New York, 1989.

42. Chowdhury, A. J. S.; Cheetham, A. K.; Cairns, J. A. J. Catal. 1985,
$95,353$.

43. Klug, H.; Alexander, L. X-ray Diffraction Procedure; Wiley \& Sons: New York, 1954.

44. McBreen, J.; Mukerjee, S. J. Electrochem. Soc. 1995, 142, 3399.

45. Hadzi-Jordanov, S.; Angerstein-Kozlowska, H.; Vukovic, M.; Conway, B. E. J. Phys. Chem. 1977, 81, 2271.

46. Ticanelli, E.; Beery, J. G.; Paffett, M. T.; Gottesfeld, S. J. Electroanal. Chem. 1989, 258, 61.

47. Ianniello, R.; Schmidt, V. M.; Stimming, U.; Stumper, J.; Wallu, A. Electrochim. Acta 1994, 39, 1863. 